\title{
Sponge bioerosion accelerated by ocean acidification across species and latitudes?
}

\author{
M. Wisshak · C. H. L. Schönberg • A. Form • \\ A. Freiwald
}

Received: 19 July 2013/Revised: 24 January 2014/ Accepted: 10 February 2014/Published online: 25 February 2014

(C) Springer-Verlag Berlin Heidelberg and AWI 2014

\begin{abstract}
In many marine biogeographic realms, bioeroding sponges dominate the internal bioerosion of calcareous substrates such as mollusc beds and coral reef framework. They biochemically dissolve part of the carbonate and liberate so-called sponge chips, a process that is expected to be facilitated and accelerated in a more acidic environment inherent to the present global change. The bioerosion capacity of the demosponge Cliona celata Grant, 1826 in subfossil oyster shells was assessed via alkalinity anomaly technique based on 4 days of experimental exposure to three different levels of carbon dioxide partial pressure $\left(p \mathrm{CO}_{2}\right)$ at ambient temperature in the coldtemperate waters of Helgoland Island, North Sea. The rate of chemical bioerosion at present-day $p \mathrm{CO}_{2}$ was quantified with $0.08-0.1 \mathrm{~kg} \mathrm{~m}^{-2}$ year $^{-1}$. Chemical bioerosion was positively correlated with increasing $p \mathrm{CO}_{2}$, with rates more than doubling at carbon dioxide levels predicted for the end of the twenty-first century, clearly confirming that $C$. celata bioerosion can be expected to be enhanced with
\end{abstract}

Communicated by H.-D. Franke.

M. Wisshak $(\bowtie) \cdot$ A. Freiwald

Marine Research Department, SENCKENBERG am Meer,

26382 Wilhelmshaven, Germany

e-mail: max.wisshak@senckenberg.de

M. Wisshak

Biologische Anstalt Helgoland, Alfred-Wegener-Institute for

Polar and Marine Research, 27498 Helgoland, Germany

\section{H. L. Schönberg}

Australian Institute of Marine Science (AIMS), Oceans Institute, University of Western Australia, Crawley, WA 9006, Australia

A. Form

Marine Biogeochemistry, GEOMAR Helmholtz Centre for

Ocean Research, 24105 Kiel, Germany progressing ocean acidification (OA). Together with previously published experimental evidence, the present results suggest that OA accelerates sponge bioerosion (1) across latitudes and biogeographic areas, (2) independent of sponge growth form, and (3) for species with or without photosymbionts alike. A general increase in sponge bioerosion with advancing OA can be expected to have a significant impact on global carbonate (re)cycling and may result in widespread negative effects, e.g. on the stability of wild and farmed shellfish populations, as well as calcareous framework builders in tropical and cold-water coral reef ecosystems.

Keywords Ocean acidification - Bioerosion - Bioeroding sponges $\cdot$ Cliona celata $\cdot$ Helgoland $\cdot$ North Sea

\section{Introduction}

Degradation of calcareous materials by marine bioerosion is an important recycling process that acts at different scales and is performed by a wide spectrum of organisms employing different chemical and mechanical means in the process of attachment, grazing, or carbonate penetration (Warme 1975; Bromley 1992; Wisshak and Tapanila 2008; Tribollet et al. 2011; Wisshak 2012). Considering the significant environmental changes of our century, recent research activities pay renewed attention to bioerosion and question how it may be influenced by global developments, and whether it may outweigh calcification processes (e.g. Tribollet et al. 2009; Andersson and Gledhill 2012; Wisshak et al. 2012; Kennedy et al. 2013). The traditional focus of bioerosion research lies on tropical coral reefs, with the most comprehensive data derived from the Pacific and the Caribbean (e.g. Schönberg and Tapanila 2006), but 
in order to understand how bioerosion changes globally, we need to investigate a wider variety of settings and conditions, and for a range of dominant bioeroders.

In carbonate-dominated habitats worldwide, such as shallow warm-water as well as deep cold-water coral reefs or mollusc beds, the largest proportion of internal bioerosion is often contributed by demosponges which frequently generate 60 to over $90 \%$ of total macroborer activity (Hartman 1958; Risk et al. 1995; Freiwald and Wilson 1998; Mallela and Perry 2007), and with individual species removing around $1-10 \mathrm{~kg} \mathrm{~m}^{-2}$ year $^{-1}$ substrate or occasionally even more (e.g. Schönberg 2001; Calcinai et al. 2007). According to our present knowledge, species of the family Clionaidae are the most diverse, abundant, and detrimental representatives among the bioeroding sponges, with the widest range of distribution from the equator to polar seas (van Soest et al. 2013). Clionaids combine a number of characteristics that allow a variety of different experimental angles, resulting in a wide spectrum of information that can potentially be gained: Most clionaid species are obligate endoliths with only minute portions of tissue in contact with the surrounding water, the papillae (alpha form; e.g. Rosell 1994). Other clionaids are still endolithic, but connect the papillae with a continuous layer of epilithic tissue (beta form), and a third type of clionaids grows into large, free-living individuals that are thought to retain their potential for bioerosion (gamma form; e.g. Hatch 1980; Schönberg 2008). Despite living within calcium carbonate and dissolving the material, clionaids are nevertheless functional sponges and obtain their food by filter feeding (Schönberg and Wisshak 2012). However, just like corals, some clionaids live in highly specified symbioses with dinoflagellates of the genus Symbiodinium (zooxanthellae) that supplement the sponges' energy requirements (e.g. Schönberg and Loh 2005; Weisz et al. 2010; Hill and Hill 2012). All the above circumstances create a unique opportunity to assess possible changes of sponge-generated bioerosion across a wide range of settings and will thus enable various approaches to better explain global changes of bioerosion.

A series of experiments by the present authors demonstrated a significant increase in sponge bioerosion rates with increasing carbon dioxide partial pressure $\left(p \mathrm{CO}_{2}\right)$. This was achieved by simulating the effect of progressing ocean acidification $(\mathrm{OA})$ and recording the responses of the dominant tropical bioeroding sponge Cliona orientalis Thiele, 1900 from the Australian Great Barrier Reef (Wisshak et al. 2012, 2013). We hypothesise that not only this particular species, but bioeroding sponges in general can be expected to show enhanced bioerosion capacities under elevated $p \mathrm{CO}_{2}$. Our argument is based on the fact that despite having representatives in 5 different taxonomic orders (van Soest et al. 2013), all bioeroding sponges share a common mode of substrate penetration comprising biochemical dissolution of calcium carbonate in concert with the mechanical extraction of so-called sponge chips of 15-100 $\mu \mathrm{m}$ in diameter (e.g. Rützler and Rieger 1973; Schönberg 2008). While the ratio between the chemical and mechanical component of sponge bioerosion appears to vary strongly among species or habitats (e.g. Rützler and Rieger 1973; Zundelevich et al. 2007; Nava and Carballo 2008; see Wisshak et al. 2013 for an overview), we proposed that it is mainly the chemical dissolution which is sensitive to ambient $\mathrm{pH}$ and will thus be accelerated in a more acidic environment (Wisshak et al. 2013). The rate of mechanical extraction of sponge chips, however, remains relatively constant in case of $C$. orientalis (figure 7 in Wisshak et al. 2013). This line of reasoning was supported most recently by Fang et al. (2013) who found a significant increase in chemical, but stable mechanical sponge bioerosion rates under a series of combined acidification and warming scenarios.

Herein, we extend our experimental approach across species and latitudes by studying the effect of increasing $p \mathrm{CO}_{2}$ on the bioeroding sponge Cliona celata Grant, 1826. C. celata was described from the North Sea as the type species of the genus Cliona and was thought to be cosmopolitan (van Soest et al. 2013). However, in reality, it is a species complex of morphologically very similar species (Xavier et al. 2010; de Paula et al. 2012). Nevertheless, research on $C$. cf. celata has a long tradition elaborating on physiological and ecological aspects, with detailed historic work available early on, e.g. growth forms (Topsent 1888), growth rates (Nicol and Reisman 1976), reproduction (e.g. Warburton 1961; Wapstra and van Soest 1987), effects of environmental factors (e.g. Hartman 1957, 1958; Emson 1966; Driscoll 1967; Nicol and Reisman 1976), and classic bioerosion research (e.g. Warburton 1958a; Cobb 1969, 1975; Hatch 1980). In temperate waters, C. cf. celata and closely related species are usually the dominant bioeroding sponges and are devastating pests in mollusc shells (e.g. Warburton 1958b). Assuming conspecificity with Grant's (1826) specimen from Scotland, we worked with C. celata from the cold-temperate waters off Helgoland Island in the German North Sea, where it thrives in oyster and other mollusc shells (Arndt 1928).

\section{Materials and methods}

Subfossil calcitic Ostrea edulis Linnaeus, 1758 oyster shells heavily infested with the bioeroding sponge $C$. celata (Fig. 1a, b) were dredge sampled in the deep trough south of Helgoland Island in 50-55 m water depth and transported to the Helgoland Alfred Wegener Institute. Epibionts and sediment particles were removed from the shells 

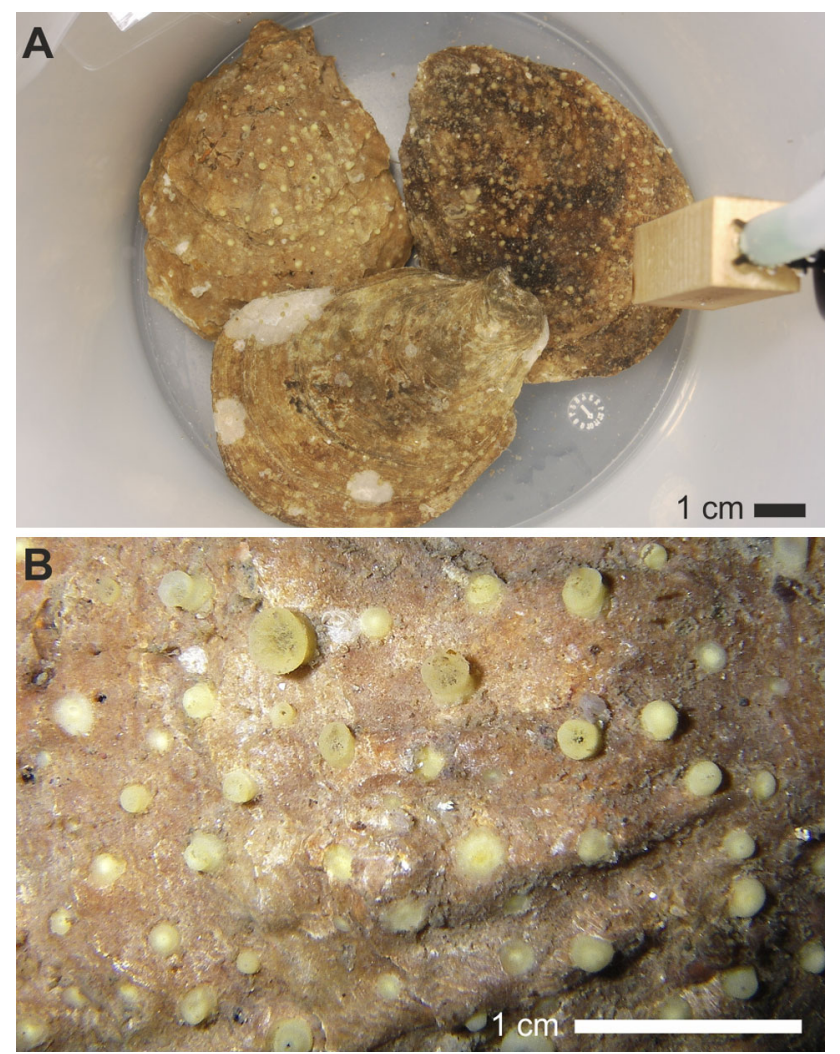

Fig. 1 a Three subfossil $O$. edulis valves heavily infested with the bioeroding sponge $C$. celata resting on the bottom of a bioreactor in 2.51 of prefiltered seawater. Perturbation (stopped while taking the picture) with premixed $p \mathrm{CO}_{2}$ treatment gas was provided via inert silicon tubing and an airstone (right) with the bubbles inducing water circulation in the beaker and preventing dysoxia. b Close-up of one of the oyster valves showing numerous inhaling (ostiae) and exhaling papillae (oscula), partly contracted after handling

by gentle cleaning with a soft toothbrush and forceps, after which the sponges acclimated 4 days in flow-through aquaria in a constant temperature room at $15{ }^{\circ} \mathrm{C}$, the typical ambient temperature for local July seawater. Room and water temperatures were monitored with Starmon Mini high-resolution temperature loggers with an accuracy of $\pm 0.02{ }^{\circ} \mathrm{C}$ in 5 -min intervals (Star Oddi, Iceland). Salinity (PSS scale) and $\mathrm{pH}$ (NBS scale) were measured every $24 \mathrm{~h}$ with a SevenGo DUO (Mettler-Toledo, Switzerland) equipped with an InLab Expert Pro-ISM and an InLab 738-ISM probe, respectively, both calibrated daily with NIST certified buffer solutions.

The sponges were subjected to present-day $(392.3 \pm$ $15.6 \mu \mathrm{atm})$, moderately elevated $(643.5 \pm 25.5 \mu \mathrm{atm})$, and strongly elevated $(1,134.9 \pm 31.1 \mu \mathrm{atm}) \quad p \mathrm{CO}_{2}$ levels established by perturbation in a semi-closed system (Fig. 2; Table 2). Each treatment consisted of a set of five replicate bioreactors, each with 3-5 oyster shells (Fig. 1a) in 2.51 of seawater that was previously run though a $\sim 5-\mu \mathrm{m}$ filter in order to exclude large calcareous plankton but retaining picoplankton $(<3 \mu \mathrm{m})$ as the main source of nutrition for the sponges (Lynch and Phlips 2000). One blank bioreactor containing only seawater was included for monitoring and correction purposes with respect to the seawater chemistry. The bioreactors were graded 3-1 polypropylene beakers with circular covers sealed with cling film to minimise evaporation and to stabilise the $p \mathrm{CO}_{2}$ in the headspace. Evaporation was further reduced by humidifying the perturbation gases via gas-wash bottles filled with de-ionised water, resulting in negligible evaporation rates of only $5.8 \pm 4.2 \mathrm{ml}(<0.3 \%$ of the water volume $)$ per day on average $(n=72)$. The present-day $p \mathrm{CO}_{2}$ treatment was run with compressed air representing ambient $p \mathrm{CO}_{2}$, while the elevated $p \mathrm{CO}_{2}$ levels were specifically mixed with Digamix 5KA 36A/9 pumps on M755-1.2 consoles (H. Wösthoff, Germany) using food grade $\mathrm{CO}_{2}$ gas and compressed air. The temperature in the bioreactors was kept stable by placing them into a $150-1$ buffer tub with water adjusted to the constant room temperature of close to $15{ }^{\circ} \mathrm{C}$ by equilibrium (Tables 1, 2).

Water samples for analyses were taken and processed as described in Wisshak et al. (2012). Aliquots of culture water were sterile-filtered with $0.2-\mu \mathrm{m}$ PES filters at the start $(0 \mathrm{~h})$, mid-way $(48 \mathrm{~h})$ and at the end $(96 \mathrm{~h})$ of the experiments. Samples for dissolved inorganic carbon (DIC; $2 \times 4 \mathrm{ml}$ ) and total alkalinity (TA; $2 \times 50 \mathrm{ml}$ ) were treated with $0.02 \mathrm{vol} \%$ saturated $\mathrm{HgCl}_{2}$ solution to arrest all biological activity. Samples for nutrient analyses $(100 \mathrm{ml}$; at 0 and $96 \mathrm{~h}$ only) were sterile-filtered and refrigerated at $5{ }^{\circ} \mathrm{C}$ in dark until analysed. Nitrate, nitrite, and phosphate were measured photometrically (U-2000, Hitachi, Japan) according to standard methods described by Hansen and Koroleff (1999) with precision levels of \pm 0.5 , \pm 0.02 , and $\pm 0.05 \mu \mathrm{mol} \mathrm{l}^{-1}$, respectively; ammonium was quantified fluorometrically (SFM 25, Kontron Instruments, Germany) according to Holmes et al. (1998) to $\pm 0.08 \mu \mathrm{mol} \mathrm{l}^{-1}$. TA was determined in duplicate, using potentiometric open-cell titration following Dickson et al. (2003). Seawater was weighed (1416B MP8-1, Sartorius AG, Germany) and titrated with $0.005 \mathrm{~N}$ hydrochloric acid in an automatic titrator (Titrando 808, Deutsche Metrohm $\mathrm{GmbH} \&$ Co. KG, Germany); the average precision between duplicate water samples was $\leq 4 \mu \mathrm{mol} \mathrm{kg} \mathrm{kg}^{-1}$. DIC was measured photochemically following Stoll et al. (2001) using an automated segmented flow analyser (QuAAtro, Bran+Luebbe, Germany) equipped with an autosampler $\left( \pm 5 \mu \mathrm{mol} \mathrm{kg}^{-1}\right.$ precision). Both, TA and DIC were calibrated with certified seawater reference material (CRM standards supplied by Andrew Dickson, Scripps Institution of Oceanography).

The carbonate system was computed from the measured TA, DIC, temperature, and salinity using the CO2SYS program (EXCEL macro v. 2.1; Pierrot et al. 2006) with 
Fig. 2 Set-up of the experimental system situated in a constant temperature room at the Helgoland Alfred Wegener Institute. Individual sealed bioreactors (five replicates per treatment level), carrying 3-5 sponge-bearing oyster shells, and one bioreactor with seawater only for monitoring purposes, all placed into a larger $15^{\circ} \mathrm{C}$ buffer tank to maintain ambient temperature. The moderately and strongly elevated $p \mathrm{CO}_{2}$ levels were adjusted by perturbation with specifically mixed gases; for present-day $p \mathrm{CO}_{2}$, compressed air was used
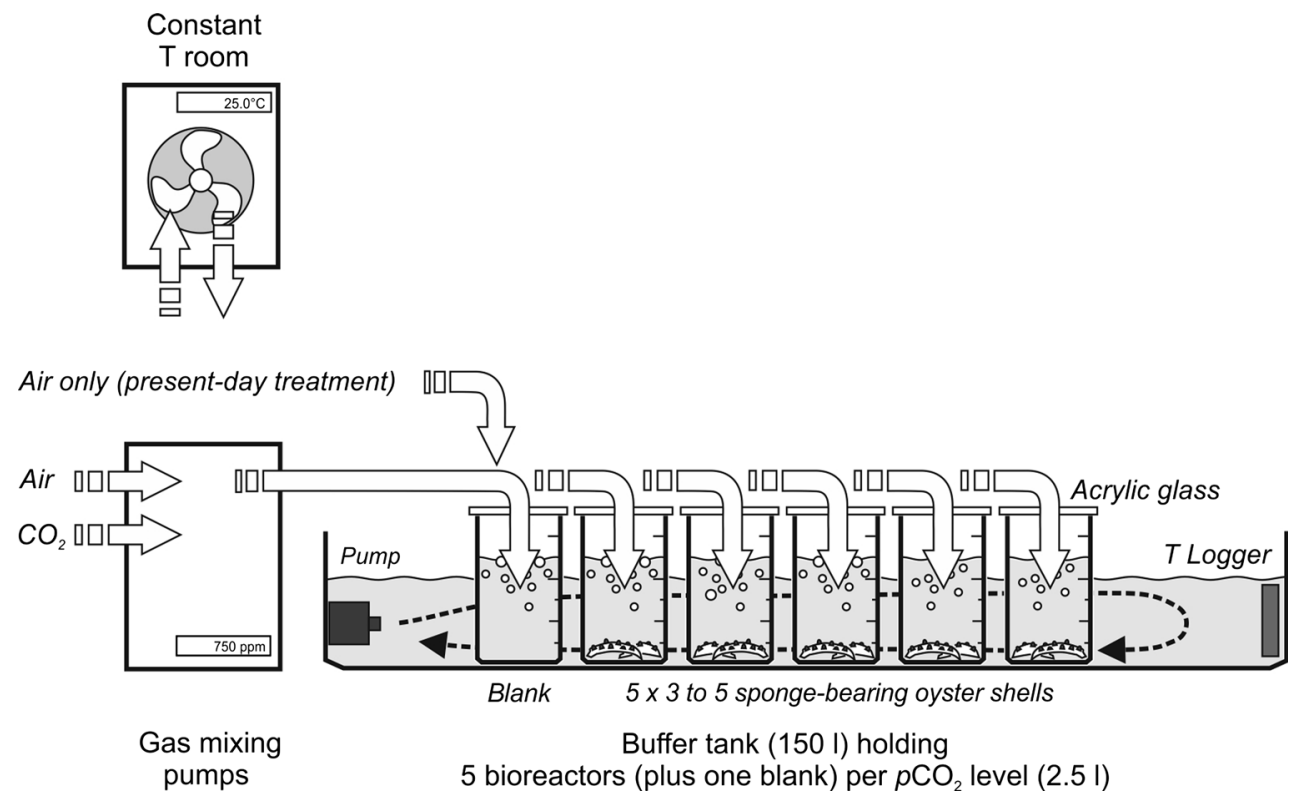

\begin{tabular}{|c|c|c|c|}
\hline Variable with [unit] or (scale) & $\begin{array}{l}\mathrm{A} 1 \\
\text { Present-day } p \mathrm{CO}_{2}\end{array}$ & $\begin{array}{l}\mathrm{B} 1 \\
\text { Present-day } p \mathrm{CO}_{2}\end{array}$ & $\begin{array}{l}\mathrm{C} 1 \\
\text { Present-day } p \mathrm{CO}_{2}\end{array}$ \\
\hline Temperature $\left[{ }^{\circ} \mathrm{C}\right]$ & $14.98 \pm 0.08$ & $15.08 \pm 0.03$ & $15.14 \pm 0.00$ \\
\hline Salinity (PSS) & $30.28 \pm 0.04$ & $30.37 \pm 0.03$ & $31.10 \pm 0.02$ \\
\hline pH (NBS scale) & $8.01 \pm 0.01$ & $7.99 \pm 0.02$ & $8.07 \pm 0.01$ \\
\hline DIC $\left[\mu \mathrm{mol} \mathrm{kg}^{-1}\right]$ & $2,162.8 \pm 12.3$ & $2,179.1 \pm 15.8$ & $2,130.2 \pm 18.2$ \\
\hline $\mathrm{TA}\left[\mu \mathrm{mol} \mathrm{kg}{ }^{-1}\right]$ & $2,340.2 \pm 8.1$ & $2,350.1 \pm 16.1$ & $2,340.6 \pm 14.9^{\mathrm{c}}$ \\
\hline$p \mathrm{CO}_{2}[\mu \mathrm{atm}]^{\mathrm{a}}$ & $469.5 \pm 18.8$ & $496.1 \pm 27.6$ & $403.1 \pm 19.5$ \\
\hline $\mathrm{pH}(\text { total scale })^{\mathrm{a}}$ & $8.01 \pm 0.01$ & $7.99 \pm 0.02$ & $8.07 \pm 0.01$ \\
\hline $\mathrm{HCO}_{3}{ }^{-}\left[\mu \mathrm{mol} \mathrm{kg}{ }^{-1}\right]^{\mathrm{a}}$ & $2,007.7 \pm 14.3$ & $2,026.8 \pm 16.3$ & $1,957.3 \pm 19.8$ \\
\hline $\mathrm{CO}_{3}^{2-}\left[\mu \mathrm{mol} \mathrm{kg}{ }^{-1}\right]^{\mathrm{a}}$ & $137.1 \pm 3.0$ & $133.3 \pm 5.2$ & $157.5 \pm 3.4$ \\
\hline$\Omega_{\mathrm{Ar}}^{\mathrm{a}}$ & $2.14 \pm 0.05$ & $2.08 \pm 0.08$ & $2.45 \pm 0.05$ \\
\hline$\Omega_{\mathrm{Ca}}^{\mathrm{a}}$ & $3.37 \pm 0.07$ & $3.27 \pm 0.13$ & $3.85 \pm 0.08$ \\
\hline Nitrate $\mathrm{NO}_{3}\left[\mu \mathrm{mol} 1^{-1}\right]$ & $3.73 \pm 1.72^{\mathrm{b}}$ & $5.25 \pm 3.25^{\mathrm{b}}$ & $9.12 \pm 6.74$ \\
\hline Nitrite $\mathrm{NO}_{2}\left[\mu \mathrm{mol} \mathrm{l}{ }^{-1}\right]$ & $0.52 \pm 0.65^{\mathrm{b}}$ & $0.18 \pm 0.06^{\mathrm{b}}$ & $0.20 \pm 0.05$ \\
\hline Ammonium $\mathrm{NH}_{4}\left[\mu \mathrm{mol} \mathrm{1} 1^{-1}\right]$ & $1.30 \pm 0.80^{\mathrm{b}}$ & $1.75 \pm 1.17^{\mathrm{b}}$ & $5.10 \pm 3.80$ \\
\hline Phosphate $\mathrm{PO}_{4}\left[\mu \mathrm{mol} \mathrm{1} 1^{-1}\right]$ & $0.82 \pm 0.11^{\mathrm{b}}$ & $0.91 \pm 0.35^{\mathrm{b}}$ & $1.59 \pm 0.66$ \\
\hline Infested oyster surface area $\left[\mathrm{cm}^{2}\right]$ & $73.78 \pm 9.65$ & $79.73 \pm 5.94$ & $102.15 \pm 4.49$ \\
\hline Dissolved $\mathrm{CaCO}_{3}[\mathrm{mg}]$ & $1.94 \pm 0.48$ & $1.84 \pm 0.41$ & $2.55 \pm 0.96$ \\
\hline Chemical bioerosion rate $\left[\mathrm{kg} \mathrm{m}^{-2}\right.$ year $\left.^{-1}\right]$ & $0.10 \pm 0.03$ & $0.08 \pm 0.02$ & $0.09 \pm 0.03$ \\
\hline
\end{tabular}

Table 1 Summary of experimental settings, carbonate system parameters, nutrient levels, and sponge bioerosion figures of the baseline experiment with replicate sets $\mathrm{A} 1, \mathrm{~B} 1$, and $\mathrm{C} 1$ (all present-day $p \mathrm{CO}_{2}$ )

All values are given as total means across

bioreactors \pm standard deviation for the five replicates per treatment and 4 days of exposure

a Carbonate system parameters computed with the software CO2SYS

${ }^{b}$ Missing start values interpolated from blank $96 \mathrm{~h}$ values of $\mathrm{A} 1$ and $\mathrm{B} 1$

c One faulty TA value (extreme outlier) interpolated from $0 \mathrm{~h}$ and $48 \mathrm{~h}$ values
(Smith and Key 1975; Chisholm and Gattuso 1991), including a correction for nitrogen nutrients and phosphate according to Jacques and Pilson (1980), and following the TA definition of Dickson et al. (2003) (Eq. 1).

$$
\begin{aligned}
\Delta \mathrm{CaCO}_{3}= & 0.5 \times\left[\Delta \mathrm{TA}+\Delta \mathrm{PO}_{4}-\Delta \mathrm{NH}_{4}+\Delta\left(\mathrm{NO}_{3}+\mathrm{NO}_{2}\right)\right] \\
& \times 100 \times V_{\mathrm{sw}} \times \rho_{\mathrm{sw}} / 10^{3}
\end{aligned}
$$

The factor 0.5 reflects the $2: 1$ relationship between the increase in TA during carbonate dissolution, the multiplier 
Table 2 Summary of experimental settings, carbonate system parameters, nutrient levels, and sponge bioerosion figures of the three experimental treatments A2 (present-day), B2 (moderately elevated), and $\mathrm{C} 2$ (strongly elevated $p \mathrm{CO}_{2}$ )

All values are given as total means across

bioreactors \pm standard deviation for the five replicates per treatment and 4 days of exposure

${ }^{a}$ Carbonate system parameters computed with the software CO2SYS

b Two faulty DIC values (extreme outliers) calculated via $\mathrm{pH}$ and $\mathrm{TA}$

\begin{tabular}{|c|c|c|c|}
\hline Variable with [unit] or (scale) & $\begin{array}{l}\mathrm{A} 2 \\
\text { Present-day } \\
p \mathrm{CO}_{2}\end{array}$ & $\begin{array}{l}\mathrm{B} 2 \\
\text { Moderately } \\
\text { elevated } p \mathrm{CO}_{2}\end{array}$ & $\begin{array}{l}\mathrm{C} 2 \\
\text { Strongly } \\
\text { elevated } p \mathrm{CO}_{2}\end{array}$ \\
\hline temperature $\left[{ }^{\circ} \mathrm{C}\right]$ & $15.14 \pm 0.00$ & $15.12 \pm 0.01$ & $15.02 \pm 0.01$ \\
\hline salinity (PSS) & $31.06 \pm 0.03$ & $31.07 \pm 0.03$ & $31.69 \pm 0.02$ \\
\hline pH (NBS scale) & $8.11 \pm 0.01$ & $7.98 \pm 0.02$ & $7.78 \pm 0.00$ \\
\hline $\mathrm{DIC}\left[\mu \mathrm{mol} \mathrm{kg}{ }^{-1}\right]$ & $2,119.1 \pm 11.0$ & $2,219.0 \pm 13.3$ & $2,344.4 \pm 4.5^{\mathrm{b}}$ \\
\hline $\mathrm{TA}\left[\mu \mathrm{mol} \mathrm{kg}{ }^{-1}\right]$ & $2,330.3 \pm 7.6$ & $2,352.1 \pm 13.0$ & $2,403.0 \pm 7.5$ \\
\hline$p \mathrm{CO}_{2}[\mu \mathrm{atm}]^{\mathrm{a}}$ & $392.3 \pm 15.6$ & $643.5 \pm 25.5$ & $1,134.9 \pm 31.1$ \\
\hline $\mathrm{pH}(\text { total scale })^{\mathrm{a}}$ & $8.07 \pm 0.01$ & $7.89 \pm 0.02$ & $7.67 \pm 0.01$ \\
\hline $\mathrm{HCO}_{3}{ }^{-}\left[\mu \mathrm{mol} \mathrm{kg}{ }^{-1}\right]^{\mathrm{a}}$ & $1,946.6 \pm 13.0$ & $2,084.5 \pm 14.0$ & $2,229.9 \pm 4.0$ \\
\hline $\mathrm{CO}_{3}^{2-}\left[\mu \mathrm{mol} \mathrm{kg}{ }^{-1}\right]^{\mathrm{a}}$ & $157.6 \pm 3.3$ & $110.0 \pm 3.8$ & $71.3 \pm 2.1$ \\
\hline$\Omega_{\mathrm{Ar}}^{\mathrm{a}}$ & $2.46 \pm 0.05$ & $1.71 \pm 0.06$ & $1.11 \pm 0.03$ \\
\hline$\Omega_{\mathrm{Ca}}^{\mathrm{a}}$ & $3.85 \pm 0.08$ & $2.69 \pm 0.09$ & $1.74 \pm 0.05$ \\
\hline nitrate $\mathrm{NO}_{3}\left[\mu \mathrm{mol} \mathrm{l}{ }^{-1}\right]$ & $16.28 \pm 4.51$ & $21.51 \pm 5.07$ & $30.91 \pm 7.85$ \\
\hline nitrite $\mathrm{NO}_{2}\left[\mu \mathrm{mol} \mathrm{1} 1^{-1}\right]$ & $0.29 \pm 0.07$ & $0.41 \pm 0.08$ & $0.43 \pm 0.11$ \\
\hline ammonium $\mathrm{NH}_{4}\left[\mu \mathrm{mol} \mathrm{l} 1^{-1}\right]$ & $1.33 \pm 0.61$ & $2.56 \pm 1.30$ & $4.06 \pm 3.43$ \\
\hline phosphate $\mathrm{PO}_{4}\left[\mu \mathrm{mol} \mathrm{l}{ }^{-1}\right]$ & $0.73 \pm 0.17$ & $1.17 \pm 0.35$ & $1.47 \pm 0.38$ \\
\hline Infested oyster surface area $\left[\mathrm{cm}^{2}\right]$ & $73.78 \pm 9.65$ & $79.73 \pm 5.94$ & $102.15 \pm 4.49$ \\
\hline dissolved $\mathrm{CaCO}_{3}[\mathrm{mg}]$ & $0.84 \pm 0.31$ & $1.50 \pm 0.55$ & $4.38 \pm 0.72$ \\
\hline dissolved $\mathrm{CaCO}_{3}[\%$ of baseline $]$ & $43.56 \pm 15.74$ & $81.76 \pm 26.93$ & $171.79 \pm 28.34$ \\
\hline chemical bioerosion rate $\left[\mathrm{kg} \mathrm{m}^{-2}\right.$ year $\left.^{-1}\right]$ & $0.04 \pm 0.02$ & $0.07 \pm 0.03$ & $0.16 \pm 0.02$ \\
\hline chemical bioerosion rate [\% of present-day] & $100.00 \pm 38.06$ & $164.40 \pm 63.47$ & $367.65 \pm 49.47$ \\
\hline
\end{tabular}

100 is the molecular mass of $\mathrm{CaCO}_{3}, V_{\mathrm{sw}}$ is the seawater volume per bioreactor [1], $s_{\mathrm{W}}$ is the density of seawater $\left[\mathrm{kg} \mathrm{l}^{-1}\right]$ as a function of temperature and salinity calculated with ' $R$ ' using the package 'SeaCarb' version 2.4 (http:// www.cran.r-project.org/package=seacarb), and the divider $10^{3}$ converts to the weight unit milligrams.

Even under strongly elevated $p \mathrm{CO}_{2}$, the treatment water remained saturated with respect to both, aragonite (minimum $\Omega_{\mathrm{Ar}}=1.02$ ) and calcite (minimum $\Omega_{\mathrm{Ca}}=1.59$ ), the latter representing the major skeletal component of the substrate oysters. Abiogenic carbonate dissolution was thus assumed negligible. While macroborers other than the sponges were not observed in the selected oyster shells, the presence of microbioerosion cannot entirely be ruled out. However, its contribution to the bioerosion rates was assumed to be negligible relative to the sponge bioerosion activity, because the samples were taken from dys- to aphotic and cold-temperate waters, where microbioerosion is very slow and largely limited to the activity of heterotrophic fungi (Wisshak 2006). Moreover, controlled experiments on coral samples with bioeroding sponges from shallow tropical waters, where rates of microbioerosion are one to two magnitudes higher than what could be expected in the subphotic North Sea, yielded at most only a very low contribution of carbonate dissolution other than by the bioeroding sponge (Wisshak et al. 2012; Fang et al. 2013).
C. celata bioerosion capacity was assessed in two complementing ways: During the first approach, all available sponge-infested shells were distributed into 15 bioreactors (3-5 shells per bioreactor) and were kept for $96 \mathrm{~h}$ at present-day $p \mathrm{CO}_{2}$, after which the amount of dissolved carbonate per bioreactor was quantified as baseline for chemical bioerosion of $C$. celata in our experimental setup. Following at least 4 days of recovery in a flow-through tank, the same selection of oyster shells was submitted to a second treatment with one replicate set of five bioreactors each at present-day, moderately elevated, or strongly elevated $p \mathrm{CO}_{2}$ levels. From the difference in the recorded bioerosion capacity between the first and second exposure, the per cent increase was calculated, making the results independent from number, size, and shape of the oysters per bioreactor. Resulting values were subjected to linear regression analyses. The advantage of this relative approach is the independence from the conventionally used bioerosion rate, i.e. avoiding a normalisation procedure to substrate surface. However, this normalisation was also tested in an alternative approach, in which the amount of dissolved $\mathrm{CaCO}_{3}$ was expressed as chemical bioerosion in kilograms per square metre and year $\left(\mathrm{kg} \mathrm{m}^{-2}\right.$ year $\left.^{-1}\right)$. This was achieved by relating the calculated mass of dissolved carbonate to the summed planar surface area of the oyster shells in each bioreactor, which was determined with the public domain software ImageJ 1.46r. Since most of the 
thin oyster valves were completely penetrated by the sponge (papillae on and across both surfaces), the mean of the upper and lower surface area of each oyster shell was considered. The resulting values were then plotted relative to the $p \mathrm{CO}_{2}$ determined from each bioreactor and consequently used for linear regression analyses (SigmaPlot 12, Systat, USA), with the comparison between the present-day treatment and the baseline experiment serving as control for potential tank and handling effects. For a complementing specification of significance levels, data from the baseline experiment as well as the various $p \mathrm{CO}_{2}$ treatments were additionally subjected to one-way ANOVAs including multiple-comparison post hoc tests (Holm-Sidak test) after confirming normal distribution (Shapiro-Wilk test) and testing equal variance about the group means (SigmaPlot 12, Systat, USA). Finally, present findings for $C$. celata were compared to our previous results obtained for C. orientalis (Wisshak et al. 2012, 2013) in order to evaluate whether different bioeroding sponge species may react differently to environmental changes.

\section{Results}

The applied experimental settings, the established carbonate system parameters and nutrient levels, and the sponge bioerosion figures are summarised in Table 1 for the baseline experiment, and Table 2 for the present-day, moderately elevated, and strongly elevated target $p \mathrm{CO}_{2}$ levels. In the baseline experiment, 1.94, 1.84, and $2.55 \mathrm{mg}$ of $\mathrm{CaCO}_{3}$ were dissolved in each bioreactor by the sponge per day during 4 days of exposure at constant ambient temperature. Normalised for the oysters' infested surface area, these values translate into mean chemical bioerosion rates of $0.10,0.08$, and $0.09 \mathrm{~kg} \mathrm{~m}^{-2}$ year $^{-1}$ for the three sets of replicates (Table 1; Fig. 3a). These values did not significantly differ from each other (Table 3 ). In contrast, in the subsequent experimental treatments, the amount of dissolved carbonate differed strongly between the three $p \mathrm{CO}_{2}$ levels of $392 \mu \mathrm{atm}$ (present-day), $644 \mu \mathrm{atm}$ (moderately elevated), and 1,135 $\mu \mathrm{atm}$ (strongly elevated), with the respective mean rates of $0.04,0.07$, and $0.16 \mathrm{~kg} \mathrm{~m}^{-2}$ year $^{-1}$ (Table 2). In the present-day and moderately elevated treatments, the amount of dissolved carbonate was lower than in the baseline experiment, whereas in the strongly elevated treatment, the dissolution was enhanced. An optional correction for this negative tank or handling effect adding the difference between the baseline experiment and the present-day treatment would yield respective mean rates of $0.10,0.13$, and
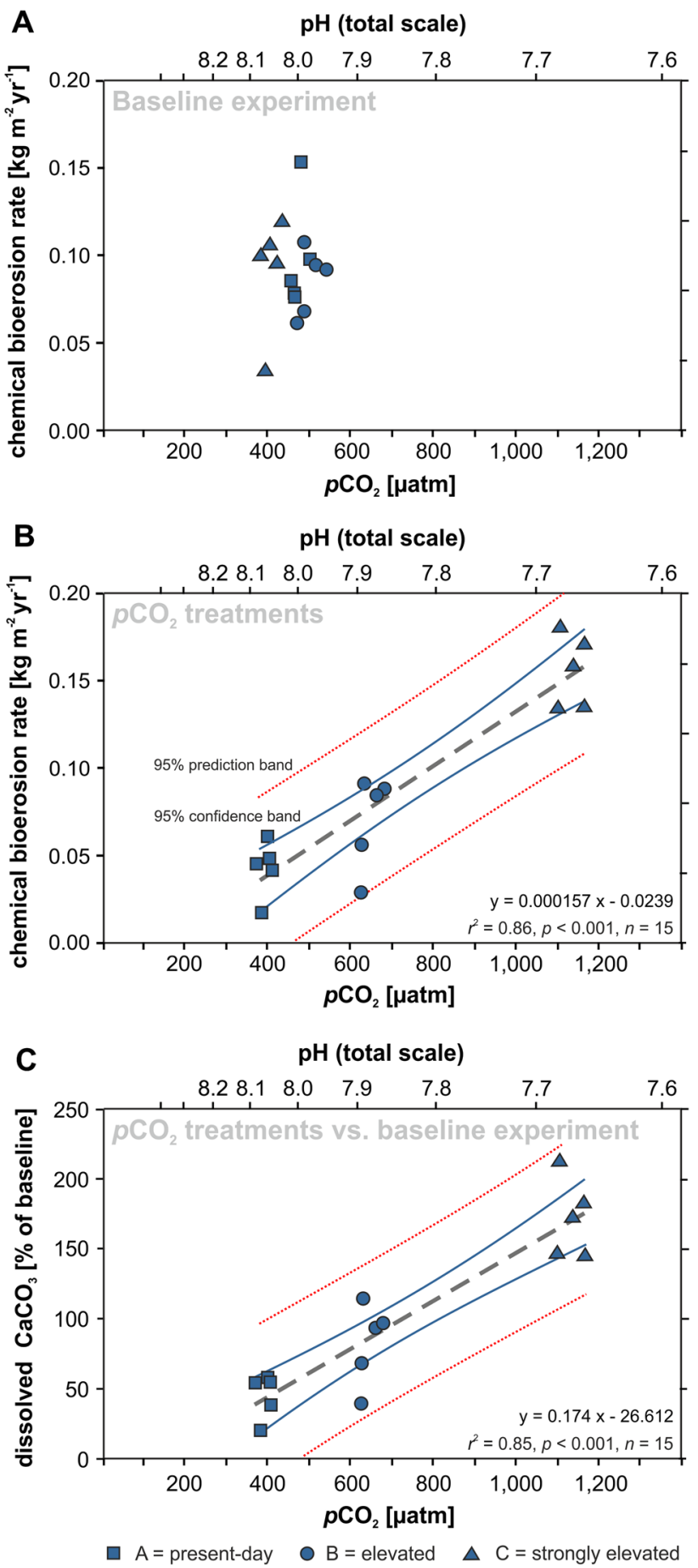

Fig. 3 Chemical bioerosion of C. celata as a function of $p \mathrm{CO}_{2}$ and pH. a $\mathrm{CaCO}_{3}$ dissolved by chemical sponge bioerosion in the baseline experiment normalised for infested oyster surface area and converted into bioerosion rates. b Highly significant positive linear regression of bioerosion rates with increasing $p \mathrm{CO}_{2}$ and decreasing $\mathrm{pH}$ levels, respectively. c Highly significant linear regression of the chemical bioerosion expressed as per cent of the respective values in the baseline experiment (independent of normalisation to surface area) 
Table 3 Results of the one-way ANOVAs including Holm-Sidak pairwise post hoc comparisons for the various data sets derived from the baseline experiment (replicate sets $\mathrm{A} 1-\mathrm{C} 1=$ present-day $\left.p \mathrm{CO}_{2}\right)$ and the three $p \mathrm{CO}_{2}$ treatments $(\mathrm{A} 2=$ present-day, $\mathrm{B} 2=$ moderately elevated, $\mathrm{C} 2$ = strongly elevated $p \mathrm{CO}_{2}$ )

\begin{tabular}{|c|c|c|c|c|}
\hline \multirow[t]{2}{*}{ Data set } & \multicolumn{2}{|c|}{ One-way ANOVA } & \multicolumn{2}{|c|}{ Holm-Sidak pairwise comparison } \\
\hline & $p$ & $F$ & pair & $p$ \\
\hline \multirow{3}{*}{$\begin{array}{l}\text { Chemical sponge bioerosion rates in } p \mathrm{CO}_{2} \text { baseline } \\
\text { experiment }\end{array}$} & \multirow[t]{3}{*}{0.775} & \multirow[t]{3}{*}{0.261} & A1 versus B1 & $>0.05$ \\
\hline & & & $\mathrm{A} 1$ versus $\mathrm{C} 1$ & $>0.05$ \\
\hline & & & $\mathrm{B} 1$ versus $\mathrm{C} 1$ & $>0.05$ \\
\hline \multirow{3}{*}{$\begin{array}{l}\text { Chemical sponge bioerosion rates in } p \mathrm{CO}_{2} \\
\text { treatments }\end{array}$} & \multirow[t]{3}{*}{$<0.001^{*}$} & \multirow[t]{3}{*}{36.938} & A 2 versus B2 & 0.071 \\
\hline & & & $\mathrm{A} 2$ versus $\mathrm{C} 2$ & $<0.001 *$ \\
\hline & & & $\mathrm{B} 2$ versus $\mathrm{C} 2$ & $<0.001^{*}$ \\
\hline \multirow{3}{*}{$\begin{array}{l}\text { Chemical sponge bioerosion rates in } p \mathrm{CO}_{2} \\
\text { treatments expressed in per cent of the rate at } \\
\text { present-day } p \mathrm{CO}_{2} \text { (treatment A2) }\end{array}$} & \multirow[t]{3}{*}{$<0.001 *$} & \multirow[t]{3}{*}{36.938} & $\mathrm{~A} 2$ versus $\mathrm{B} 2$ & 0.071 \\
\hline & & & $\mathrm{A} 2$ versus $\mathrm{C} 2$ & $<0.001^{*}$ \\
\hline & & & $\mathrm{B} 2$ versus $\mathrm{C} 2$ & $<0.001^{*}$ \\
\hline \multirow{3}{*}{$\begin{array}{l}\text { Dissolved } \mathrm{CaCO}_{3} \text { in the three } p \mathrm{CO}_{2} \text { treatments } \\
\text { expressed in per cent of the respective values in } \\
\text { the baseline experiment }\end{array}$} & \multirow[t]{3}{*}{$<0.001 *$} & \multirow[t]{3}{*}{33.371} & A versus $B$ & $0.0035^{*}$ \\
\hline & & & A versus $C$ & $<0.001^{*}$ \\
\hline & & & $\mathrm{B}$ versus $\mathrm{C}$ & $<0.001^{*}$ \\
\hline
\end{tabular}

Number of replicates $n=5$ per treatment. Significant differences marked with asterisk

$0.21 \mathrm{~kg} \mathrm{~m}^{-2}$ year $^{-1}$ instead. Either way, these chemical bioerosion rates differed significantly from each other in the treatment series (Table 3 ) and showed a highly significant positive linear correlation with $\mathrm{pCO}_{2}\left(r^{2}=0.86\right.$, $p<0.001, n=15$; Fig. 3b). Expressed as per cent of the chemical bioerosion rate in the present-day $p \mathrm{CO}_{2}$ among the treatments (Table 2), the significance levels of the oneway ANOVA and the linear regression are the same as for the absolute rates across the treatments (Table 3 ). Independent of normalisation to surface area, the dissolved $\mathrm{CaCO}_{3}$ expressed as per cent of the respective values in the baseline experiment also differed significantly from each other (Table 3) and again showed a highly significant positive linear correlation with ${ }^{2} \mathrm{CO}_{2} \quad\left(r^{2}=0.85\right.$, $p<0.001, n=15$; Fig. 3c). In summary, the linear regression models yielded the following equations for chemical bioerosion of $C$. celata as a function of $p \mathrm{CO}_{2}$ (Eq. 2), pH (Eq. 3), and expressed as per cent of the mean rate in the second present-day treatment (Eq. 4):

$$
\begin{aligned}
& \text { chemical bioerosion rate }\left[\mathrm{kg} \mathrm{m}^{-2} \text { year }^{-1}\right] \\
& =0.000157 \mathrm{CO}_{2}[\mu \mathrm{atm}]-0.0239
\end{aligned}
$$

chemical bioerosion rate $\left[\mathrm{kg} \mathrm{m}^{-2}\right.$ year $\left.^{-1}\right]$

$$
=-0.285 \mathrm{pH}(\text { total scale })+2.331
$$

chemical bioerosion [\% of present-day rate]

$$
=0.369 \mathrm{CO}_{2}[\mu \mathrm{atm}]-56.235
$$

Comparing chemical bioerosion of $C$. celata and of the congeneric $C$. orientalis, enhanced bioerosion capacities with $p \mathrm{CO}_{2}$ displayed the same trend (Fig. 4), despite the different provenance and biology of the two species.
Chemical bioerosion rates were smaller for the aphotosynthetic cold-water species $C$. celata than for the photosynthetic tropical $C$. orientalis (Fig. 4a), but both species responded to the lowered $\mathrm{pH}$ with the same rate of increase as illustrated by rates converted to per cent of the respective present-day rates (Fig. 4b). All four linear regressions of the mean experimental response values yielded a very high $r^{2}$ of 0.99 .

\section{Discussion and conclusions}

Data on Cliona cf. celata bioerosion rates are sparse to date. Reis and Leão (2000) reported a range of 0.1-3.0 and means of $0.96-1.00 \mathrm{~kg}$ removed substrate $\mathrm{m}^{-2}$ year ${ }^{-1}$ from different turbid reef sites at north Bahía, Brazil. In their pH experiments, Duckworth and Peterson (2013) found a somewhat lower total bioerosion rate of $0.26 \pm 0.05 \mathrm{~kg} \mathrm{~m}^{-2}$ year $^{-1}$ for ambient conditions for the local representative of $C$. cf. celata off the coast of New York State. The mean chemical bioerosion rates in our baseline experiment (present-day $p \mathrm{CO}_{2}$ ) ranged from 0.08 to $0.10 \mathrm{~kg} \mathrm{~m}^{-2}$ year $^{-1}$. We have no data on the total bioerosion rates of $C$. celata in our experiment, but considering Warburtons' (1958a) estimation that less than $10 \%$ of carbonate is dissolved by cold-temperate $C$. cf. celata from Eastern Canada, this would indicate total maximum bioerosion rates of about $0.8-1 \mathrm{~kg} \mathrm{~m}^{-2}$ year $^{-1}$. Even though our experiment was conducted in comparatively cold waters, these values match the rates reported by Reis and Leão (2000) from the tropical W Atlantic. 

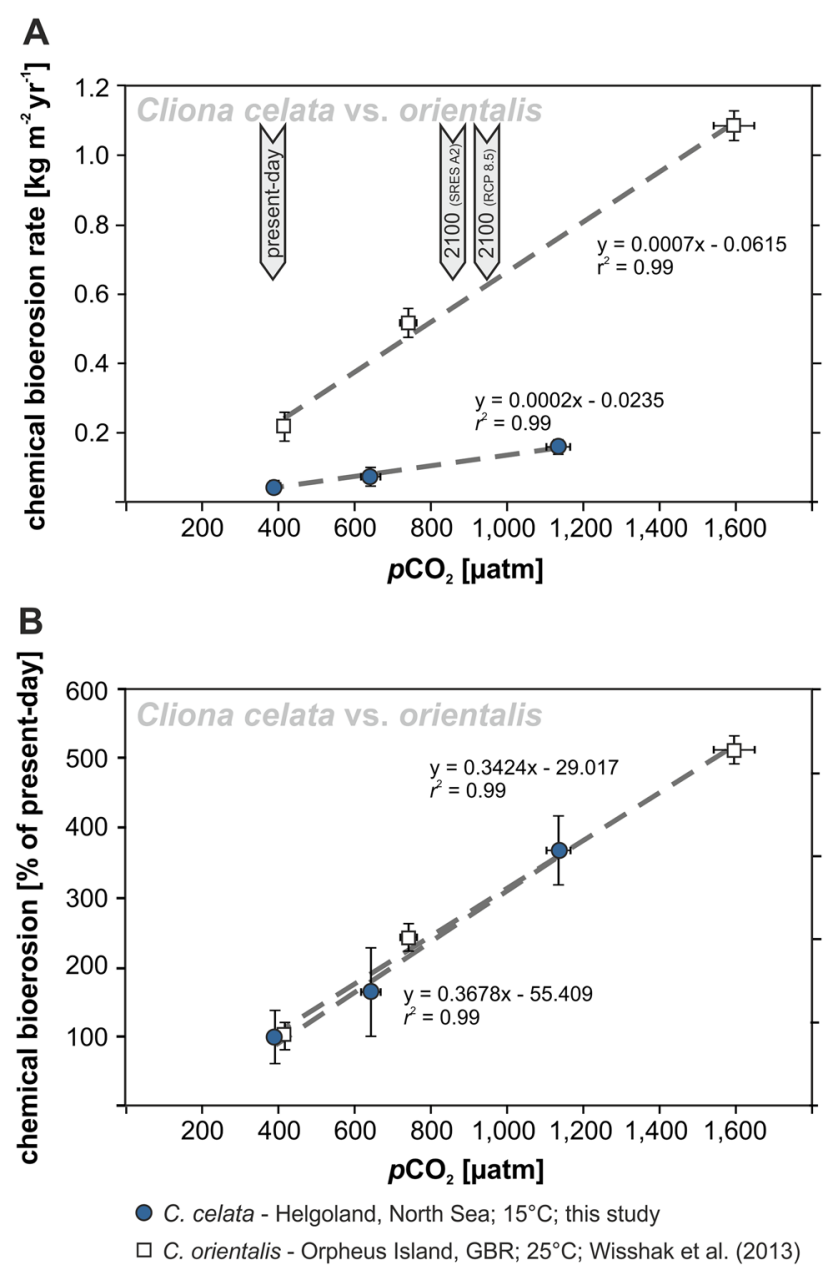

Fig. 4 Comparison of bioerosion capacity of azooxanthellate $C$. celata form cold-temperate Helgoland (this study) versus zooxanthellate $C$. orientalis from the tropical Great Barrier Reef (Wisshak et al. 2013) as a function of $p \mathrm{CO}_{2}$. a Linear regressions of mean chemical bioerosion rates. b Linear regressions of chemical bioerosion expressed as per cent of the present-day rate

The Helgoland experiment clearly indicates that $C$. celata chemical bioerosion rates depend on the seawater $p \mathrm{CO}_{2}$ and can be expected to increase with progressing $\mathrm{OA}$ (Fig. 3). Further experimental evidence for the C. celata species complex was recently provided by Duckworth and Peterson (2013) who tested $\mathrm{pH}$ differences regulated with hydrochloric acid affecting the bioerosion capacity of temperate NW Atlantic gamma form C. cf. celata explants on scallop shells. Their data are in good accordance with the present findings, with bioerosion rates more than doubling when comparing ambient $\mathrm{pH} 8.1$ with $\mathrm{pH}$ 7.8. Emson (1966) conducted an earlier experiment with specimens from British waters here assumed to be conspecific with Grant's $C$. celata. He strongly lowered the experimental $\mathrm{pH}$ to 6.8 (two experiments, one acid regulated and the other perturbation regulated), which caused negative effects on the sponge with a physiological response resulting in nearly complete closure of the oscula. However, dissociated cells of W Atlantic $C$. cf. celata survived in an even more extreme $\mathrm{pH}$ of 3.8 (acid regulated; Galtsoff and Pertzoff 1926).

The significant $p \mathrm{CO}_{2}$ dependency of $C$. celata chemical bioerosion rates found here mirrors the results for the tropical congeneric $C$. orientalis, which showed a significant increase in bioerosion capacity with increasing $p \mathrm{CO}_{2}$ both, in a 3-day closed system experiment measuring chemical bioerosion via the alkalinity anomaly technique (Wisshak et al. 2013), and in a 10 days experiment with flow-through conditions measuring total bioerosion rates by recording changes in buoyant weight (Wisshak et al. 2012). Most recently the relationship of $C$. orientalis bioerosion rates with global climate change was again confirmed by experiments carried out by Fang et al. (2013) in longer exposures of 8 weeks in a series of combined acidification and warming scenarios. Our experimentally obtained rates of chemical bioerosion of $C$. orientalis and C. celata clearly reveal the similarity in response (Fig. 4). Thereby, rates in the tropical $C$. orientalis are roughly five times higher than those determined herein for the coldtemperate C. celata, but the degree to which $p \mathrm{CO}_{2}$ increases the bioerosion rates (rates expressed as per cent of the present-day rate) is virtually identical. This is expressed in an expected 152 and $157 \%$ increase in chemical bioerosion rate by the year 2100 for $C$. celata and C. orientalis, respectively, when considering the SRES A2 emission scenario (836 ppm in 2100; IPCC 2001), and a 189 and $191 \%$ increase in case of the more recent RCP 8.5 scenario (936 ppm in 2100; Meinshausen et al. 2011). In case of $C$. orientalis, however, the total rates of sponge bioerosion increase to a much lesser degree of only 25.4 and $30.9 \%$ by the end of the century for the two emission scenarios, since the rate of mechanical bioerosion is hardly affected by OA (Wisshak et al. 2012).

In summary, our accumulated experimental evidence (Wisshak et al. 2012; 2013; this study) in concert with the results of Emson (1966), Duckworth and Peterson (2013), and Fang et al. (2013) suggests that the observed OA effect on sponge bioerosion applies (1) across latitudes, considering the wide biogeographic distribution of the investigated species, (2) for sponges of the alpha (C. celata), beta (C. orientalis), and gamma (C. cf. celata) growth form (sensu Schönberg 2008), and (3) for different feeding strategies, i.e. affecting a species without phototrophic symbionts $(C$. celata) and a species with zooxanthellae $(C$. orientalis). In addition, our data potentially also apply for different water depths, considering the known bathymetrical range of the studied species and our sample sites, even though our experiments were all conducted at atmospheric pressure. Since bioeroding sponges occur in all seas and climate zones and are among the dominant agents of 
internal macrobioerosion, an increase in sponge bioerosion with progressing $\mathrm{OA}$ is likely a global and not a local phenomenon and affects carbonate-dominated habitats and depositional systems across various biogeographic settings and water depths. Moreover, an increase in sponge bioerosion will not occur in isolation, but in concert with chemical bioerosion of other organisms such as microendoliths (e.g. Tribollet et al. 2009). Therefore, this effect can be expected to have a significant impact on the rates of global carbonate (re)cycling with ongoing global climate change. Increasing chemical bioerosion rates will result in more carbonate reef framework being dissolved as opposed to having the chance to become fossilised and incorporated in the endogenic part of the global carbonate cycle. Even though this scenario bears a positive side effect by partially buffering OA (dissolving carbonate lowers seawater $p \mathrm{CO}_{2}$; Andersson and Gledhill 2012), the expected consequences are clearly detrimental for wild and farmed shellfish populations (e.g. Warburton 1958b; Duckworth and Peterson 2013), as well as for calcareous framework builders in tropical and cold-water coral reef ecosystems (Wisshak et al. 2012; 2013; Andersson and Gledhill 2012; Kennedy et al. 2013; Fang et al. 2013).

Acknowledgments We are indebted to M. Molis, A. Wagner, M. Krüß, H. Peters, and K. Böhmer at AWI for the superb logistic support of the Helgoland experiments. The analysis of the water samples at the GEOMAR in Kiel was assisted by J. Büscher and C. Gersdorf. The valuable comments and suggestions of two anonymous referees helped improving the manuscript. This study was financially supported by the Deutsche Forschungsgemeinschaft (Grant Fr 1134/19).

\section{References}

Andersson AJ, Gledhill D (2012) Ocean acidification and coral reefs: effects on breakdown, dissolution, and net ecosystem calcification. Ann Rev Mar Sci 5:1.1-1.28

Arndt W (1928) Meeresschwämme von den deutschen Küsten. Mit Bemerkungen über die bisher in Aquarien gepflegten Meeresschwämme überhaupt. Aquarium 9:1-16

Bromley RG (1992) Bioerosion: eating rocks for fun and profit. In: Maples CG, West RR (eds) Trace fossils. The palaeontological society of America, Knoxville, pp 121-129

Calcinai B, Azzini F, Bavestrello G, Gaggero L, Cerrano C (2007) Excavating rates and boring pattern of Cliona albimarginata (Porifera: Clionaidae) in different substrata. In: Custódio MR, Lôbo-Hajdu G, Hajdu E, Muricy G (eds) Séries Livros de Museu Nacional Rio de Janeiro 28. Porifera Research. Biodiversity, innovation and sustainability, pp 203-210

Chisholm JRM, Gattuso JP (1991) Validation of the alkalinity anomaly technique for investigating calcification and photosynthesis in coral reef community. Limnol Oceanogr 36:1232-1239

Cobb WR (1969) Penetration of calcium carbonate substrates by the boring sponge, Cliona. Am Zoologist 9:783-790

Cobb WR (1975) Fine structural features of destruction of calcareous substrata by the burrowing sponge Cliona celata. Trans Am Microsc Soc 94:197-202

De Paula TS, Zilberberg C, Hajdu E, Lôbo-Hajdu G (2012) Morphology and molecules on opposite sides of the diversity gradient: four cryptic species of the Cliona celata (Porifera, Demospongiae) complex in South America revealed by mitochondrial and nuclear markers. Mol Phylogenet Evol 62:529-541

Dickson AG (1990) Standard potential of the reaction: $\mathrm{AgCl}(\mathrm{s})+1 / 2$ $\mathrm{H}_{2}(\mathrm{~g})=\mathrm{Ag}(\mathrm{s})+\mathrm{HCl}(\mathrm{aq})$, and the standard acidity constant of the ion $\mathrm{HSO}_{4}$ - in synthetic seawater from 273.15 to $318.15 \mathrm{~K}$. J Chem Thermodyn 22:113-127

Dickson AG, Millero FJ (1987) A comparison of the equilibrium constants for the dissociation of carbonic acid in seawater media. Deep-Sea Res 34:1733-1743

Dickson AG, Afghan JD, Anderson GC (2003) Reference materials for oceanic $\mathrm{CO}_{2}$ analysis: a method for the certification of total alkalinity. Mar Chem 80:185-197

Driscoll EG (1967) Attached epifauna-substrate relationships. Limnol Oceanogr 12:633-641

Duckworth AR, Peterson BJ (2013) Effects of seawater temperature and $\mathrm{pH}$ on the boring rates of the sponge Cliona celata in scallop shells. Mar Biol 160:27-35

Emson RH (1966) The reactions of the sponge Cliona celata to applied stimuli. Comp Biochem Physiol 18:805-827

Fang JKH, Mello-Athayde MA, Schönberg CHL, Kline DI, HoeghGuldberg O, Dove S (2013) Sponge biomass and bioerosion rates increase under ocean warming and acidification. Global Change Biol 19:3582-3591

Freiwald A, Wilson JB (1998) Taphonomy of modern deep, coldtemperate water coral reefs. Hist Biol 13:37-52

Galtsoff PS, Pertzoff V (1926) Some physicochemical properties of dissociated sponge cells. J Gen Physiol 10:239-255

Grant RE (1826) Notice of a new zoophyte (Cliona celata, Gr.) from the Firth of Forth. Edinburgh New Phil J 1:78-81

Hansen HP, Koroleff F (1999) Determination of nutrients. In: Grasshoff K, Kremling K, Ehrhardt M (eds) Methods of seawater analysis. Verlag Chemie, Weinheim, pp 159-228

Hartman WD (1957) Ecological niche differentiation in the boring sponges (Clionidae). Evolution 11:294-297

Hartman WD (1958) Natural history of the marine sponges of southern New England. Bull Peabody Mus Nat Hist 12:1-155

Hatch WI (1980) The implication of carbonic anhydrase in the physiological mechanism of penetration of carbonate substrata by the marine burrowing sponge Cliona celata (Demospongiae). Biol Bull 159:135-147

Hill MS, Hill A (2012) The magnesium inhibition and arrested phagosome hypotheses: new perspectives on the evolution and ecology of Symbiodinium symbioses. Biol Rev. doi:10.1111/j. 1469-185X.2012.00223.x

Holmes RM, McClelland JW, Sigman DM, Fry B, Peterson BJ (1998) Measuring ${ }^{15} \mathrm{~N}_{-} \mathrm{NH}_{4}{ }^{+}$in marine, estuarine and fresh waters: an adaptation of the ammonia diffusion method for samples with low ammonium concentrations. Mar Chem 60:235-243

IPCC (2001) Climate Change 2001: The scientific basis. Contribution of working group I to the third assessment report of the intergovernmental panel on climate change, University Press, Cambridge

Jacques TG, Pilson EQ (1980) Experimental ecology of the temperate scleractinian coral Astrangia danae. I. Partition of respiration, photosynthesis and calcification between host and symbionts. Mar Biol 60:167-178

Kennedy E, Perry CT, Halloran PR, Iglesias-Prieto R, Schönberg CHL, Wisshak M, Form AU, Carricart-Ganivet JP, Fine M, Eakin CM, Mumby PJ (2013) Avoiding coral reef functional collapse requires local and global action. Curr Biol 23: 912-918

Lynch TC, Phlips EJ (2000) Filtration of the bloom-forming cyanobacteria Synechococcus by three sponge species from Florida Bay, U.S.A. Bull Mar Sci 67:923-936 
Mallela J, Perry CT (2007) Calcium carbonate budget for two coral reefs affected by different terrestrial runoff regimes, Rio Bueno, Jamaica. Coral Reefs 26:129-145

Mehrbach C, Culberson CH, Hawley JE, Pytkowicz RM (1973) Measurement of the apparent dissociation constants of carbonic acid in seawater at atmospheric pressure. Limnol Oceanogr 18:897-907

Meinshausen M, Smith SJ, Calvin K, Daniel JS, Kainuma MLT, Lamarque J-F, Matsumoto K, Montzka SA, Raper SCB, Riahe K, Thomson A, Velders GJM, Van Vuuren DPP (2011) The RCP greenhouse gas concentrations and their extensions from 1765 to 2300. Clim Change 109:213-241

Nava H, Carballo JL (2008) Chemical and mechanical bioerosion of boring sponges from Mexican Pacific coral reefs. J Exp Biol 211:2827-2831

Nicol WL, Reisman HM (1976) Ecology of the boring sponge Cliona celata at Gardiner's Island, New York. Chesap Sci 17:1-7

Pierrot D, Lewis E, Wallace DWR (2006) MS Excel Program Developed for $\mathrm{CO}_{2}$ System Calculations, ORNL/CDIAC-105a, Carbon Dioxide Information Analysis Center, Oak Ridge National Laboratory, U.S. Department of Energy, Oak Ridge, Tennessee. doi:10.3334/CDIAC/otg.CO2SYS_XLS_CDIAC105a

Reis MAC, Leão SMAN (2000) Bioerosion rate of the sponge Cliona celata (Grant 1826) from reefs in turbid waters, north Bahia, Brazil, Proc $9^{\text {th }}$ Int Coral Reef Symp Bali, Indonesia, 273-278

Risk MJ, Sammarco PW, Edinger EN (1995) Bioerosion in Acropora across the continental shelf of the Great Barrier Reef. Coral Reefs 14:79-86

Rosell D (1994) Morphological and ecological relationships of two clionid sponges. Ophelia 40:37-50

Rützler K, Rieger G (1973) Sponge burrowing: fine structure of Cliona lampa penetrating calcareous substrata. Mar Biol 21:144-162

Schönberg CHL (2001) Small-scale distribution of Australian bioeroding sponges in shallow water. Ophelia 55:39-54

Schönberg CHL (2008) A history of sponge erosion: from past myths and hypotheses to recent approaches. In: Wisshak M, Tapanila L (eds) Current developments in bioerosion. Springer, Heidelberg, pp 165-202

Schönberg CHL, Loh WKW (2005) Molecular identity of the unique symbiotic dinoflagellates found in the bioeroding demosponge Cliona orientalis Thiele, 1900. Mar Ecol Prog Ser 299:157-166

Schönberg CHL, Ortiz J-C (2009) Is sponge bioerosion increasing? Proc $11^{\text {th }}$ Int Coral Reef Symp Fort Lauderdale, USA, pp 520-523

Schönberg CHL, Tapanila L (2006) Bioerosion research before and after 1996-a discussion of what has changed since the first international bioerosion workshop. Ichnos 13:99-102

Schönberg CHL, Wisshak M (2012) The perks of being endolithic. Aquat Biol 17:1-5

Smith SV, Key GS (1975) Carbon dioxide and metabolism in marine environments. Limnol Oceanogr 20:493-495

Stoll HM, Ruiz-Encinar J, Garcia-Alonso JI, Rosenthal Y, Klaas C, Probert I (2001) A first look at paleotemperature prospects from
$\mathrm{Mg}$ in coccolith carbonate: cleaning techniques and culture measurements. Geochem Geophy Geosyst 2:1047

Topsent E (1888) Contribution à l'étude des Clionides. Arch Zool Exp Gen 5:1-165

Tribollet A, Godinot C, Atkinson M, Langdon C (2009) Effects of elevated $\mathrm{pCO}_{2}$ on dissolution of coral carbonates by microbial euendoliths. Glob Biogeochem Cycle 23:1-7

Tribollet A, Radtke G, Golubic S (2011) Bioerosion. In: Reitner J, Thiel V (eds) Encyclopedia of geobiology. Encyclopedia of earth sciences series. Springer, Berlin, pp 117-134

Van Soest RWM, Boury-Esnault N, Hooper JNA, Rützler K, de Voogd NJ, Alvarez de Glasby B, Hajdu E, Pisera AB, Manconi R, Schönberg CHL, Janussen D, Tabachnick KR, Klautau M, Picton B, Kelly M, Vacelet J, Dohrmann M, Cristina Díaz M (2013) World Porifera Database. http://www.marinespecies.org/ porifera

Wapstra M, van Soest RWM (1987) Sexual reproduction, larval morphology and behaviour in demosponges from the southwest of the Netherlands. In: Vacelet J, Boury-Esnault N (eds) Taxonomy of porifera. NATO ASI Ser G13. Springer, Berlin, pp 281-307

Warburton FE (1958a) The manner in which the sponge Cliona bores in calcareous objects. Can J Zool 36:555-562

Warburton FE (1958b) The effects of boring sponges on oysters. Prog Rep Atlantic Coast Stn Fish Res Board Can 68:1-8

Warburton FE (1961) Inclusion of parental somatic cells in sponge larvae. Nature 191:1317

Warme JE (1975) Borings as trace fossils, and the process of marine bioerosion. In: Frey RW (ed) The study of trace fossils. Springer, Berlin, pp 181-227

Weisz JB, Massaro AJ, Ramsby BD, Hill MS (2010) Zooxanthellar symbionts shape host sponge trophic status through translocation of carbon. Biol Bull 219:189-197

Wisshak M (2006) High-latitude bioerosion: the Kosterfjord experiment. Lecture notes in earth sciences 109. Springer, Heidelberg

Wisshak M (2012) Microbioerosion. In: Knaust D, Bromley R (eds) Trace fossils as indicators of sedimentary environments, developments in sedimentology 64. Elsevier, Amsterdam, pp 213-243

Wisshak M, Tapanila L (2008) Current developments in bioerosion. Springer, Heidelberg

Wisshak M, Schönberg CHL, Form A, Freiwald A (2012) Ocean acidification accelerates reef bioerosion. PLoS ONE 7:e45124

Wisshak M, Schönberg CHL, Form A, Freiwald A (2013) Effects of ocean acidification and global warming on reef bioerosionlessons from a clionaid sponge. Aquatic Biol 19:111-127

Xavier JR, Rachello-Dolmen PG, Parra-Velandia F, Schönberg CHL, Breeuwer JAJ, van Soest RWM (2010) Molecular evidence of cryptic speciation in the 'cosmopolitan' excavating sponge Cliona celata (Porifera, Clionaidae). Mol Phylogenet Evol 56:13-20

Zundelevich A, Lazar B, Ilan M (2007) Chemical versus mechanical bioerosion of coral reefs by boring sponges-lessons from Pione cf. vastifica. J Exp Biol 210:91-96 